\title{
O FEMININO EM MANIFESTAÇÕES POPULARES: RELAÇÕES DE PODER NA CULTURA E NA EXPRESSÃO DO CARIMBÓ PARAENSE
}

\section{THE FEMININE IN POPULAR MANIFESTATIONS: POWER RELATIONSHIPS IN CULTURE AND IN THE EXPRESSION OF THE CARIMBÓ IN PARÁ/BR}

\begin{abstract}
Resumo
O presente texto é fruto de um estudo a respeito da presença feminina nas expressões e letras de canções do Carimbó paraense, dança popular tombada como patrimônio imaterial nacional. A tradição do Carimbó é tributária de uma miscigenação cultural que envolveu negros, indígenas e europeus, refletida nos detalhes da dança, nos instrumentos musicais e nas expressões corporais. É nessa complexidade expressiva e discursiva, que se revela também em nuances da vida cotidiana, que foram buscadas imagens sobre a mulher e sua análise a partir de pensamentos contemporâneos, incluindo questões suscitadas pelas teorias feministas. Estão apresentadas letras de canções e particularidades sobre mulheres envolvidas nas manifestações do Carimbó paraense.
\end{abstract}

Palavras-chave: Mulher. Dança popular. Androcentrismo.

\begin{abstract}
The present text is the result of a study about the female presence in expressions and lyrics of the Carimbó paraense, popular dance recorded as national immaterial patrimony. The tradition of the Carimbó is tributary of a cultural miscegenation that involved blacks, indigenous and Europeans, reflected in the details of dance, musical instruments and expressions of the body. It is in this expressive and discursive complexity, which also reveals itself in the nuances of everyday life, which sought images about women and their analysis from contemporary thoughts, including issues raised by feminist theories. Song lyrics and particularities about women involved in the manifestations of the Carimbó in Pará/BR are presented.
\end{abstract}

Keywords: Woman. Popular dance. Androcentrism.

Maycol Douglas Lima Silva

Universidade Federal do Triângulo Mineiro (UFTM)

E-mail: maycolmundoca@gmail.com

Andreia Aparecida Marin

Universidade Federal do Triângulo Mineiro (UFTM)

E-mail: aamarinea@gmail.com 


\section{Introdução}

Muito se tem discutido sobre a ampliação dos espaços de atuação da mulher e a superação de preconceitos e políticas de contenção da feminilidade no mundo atual. No entanto, é nesse mesmo mundo que se testemunham recorrentes casos de violência contra a mulher, de tratamento diferencial na dimensão profissional e nas relações sociais, de um reverberante discurso androcêntrico que jamais cedeu completamente à defesa de igualdade de direitos. Paira sobre a possibilidade de novas representações sobre a mulher uma diferença incontornável que fundamenta discursos e práticas machistas/patriarcalistas.

Mais que discursos, as nuances da vida cotidiana, mediada pela cultura, e as manifestações artístico-culturais, têm muito a revelar a respeito do empoderamento de mulheres em diferentes grupos sociais. Onde muitas vezes se pressente um cenário com regimes de submissão e controle da força feminina, a demonstração de centralidade nas relações de poder nos arranjos habituais da vida e de corpos travestidos de força nas expressões culturais pode revelar um constante e sutil movimento de resistência e autoafirmação.

É partindo dessa suspeita que se configura, aqui, uma busca pelas forças sutis que impulsionam uma próação feminina em um mundo marcado por conceitos restritivos sobre a mulher. $\mathrm{O}$ presente texto foi tecido a partir de uma pesquisa que tomou como ponto de partida o estudo da presença feminina no Carimbó paraense, onde se buscou analogias entre o papel social da mulher, revelado em sua vida cotidiana, no cenário do interior paraense e a força da imagem feminina nas manifestações artísticas. Esse estudo incluiu um levantamento das influências culturais a partir das quais se constituiu a dança popular paraense conhecida nos dias atuais, dada a necessidade de consideração da miscigenação cultural de índios, europeus e africanos e a inevitável transformação de hábitos e costumes das comunidades regionais.

Partimos, antes de tudo, da ideia de que o Carimbó não é uma prática que se encerra na música ou na dança, no tocar ou no fabricar dos instrumentos. A prática cultural do Carimbó envolve todo um modo de vida, que ultrapassa o limite do divertimento ou do lazer. É nesse sentido que julgamos procedente a busca de representações sobre a mulher nas expressões das danças e nas letras das canções. Os elementos advindos dessas fontes, somados à dados históricos reunidos de uma análise de documentos oficiais permitiram tecer as considerações que seguem, obedecendo à ordem de apresentação: dados históricos sobre o Carimbó paraense; revisão teórica sobre os regimes de contenção da mulher e sobre a imagens do feminino veiculadas em discursos e práticas persistentes; comentários sobre elementos destacados das letras e das expressões da dança que sugerem diferentes representações sobre a mulher.

\section{Breve histórico do Carimbó paraense}

Segundo dados do Instituto do Patrimônio Histórico e Artístico Nacional (IPHAN), na pesquisa intitulada Dossiê do Carimbó, a origem dessa prática remonta dos séculos XVII e XVIII, de acordo com crônicas de viajantes e missionários. Uma prática cultural com aproximadamente quatro séculos de existência não se conservaria intacta sendo a cultura um "corpo vivo" sujeito às modificações do tempo e das circunstâncias. É natural que a prática do Carimbó tenha sofrido diversas alterações em seus objetivos e, consequentemente, nas suas motivações.

A narrativa da criação do Carimbó nos fala de uma dança resultante da união e das influências culturais de três culturas distintas: negra, indígena e europeia. Sobre essa lógica, a dança em formato de roda representaria um elemento da cultura indígena, bem como alguns instrumentos utilizados. No batuque e no molejo estaria a contribuição dos negros e, no dançar em pares, no estalar de dedos, assim como alguns padrões melódicos, encontraríamos a porção ibérica do Carimbó.

O fato é que as regiões com maior incidência da cultura do Carimbó são regiões com profundos processos de miscigenação, como nos aponta o historiador Oscar de La Torre nos estudos acerca do Carimbó na região da Grande Vigia no Pará:

A região foi desde cedo na sua história o berço de múltiplos processos de fusão étnica marcados, porém, por tensões e relações desiguais de poder entre grupos de gênero, de classe, étnicos e raciais (Torre, 2009: 120). 
Sendo essas regiões povoadas por diferentes raízes culturais, a apropriação e assimilação da cultura do "outro" é processo quase que inevitável, mesmo que ocorra à custa de muitas tensões e conflitos. Há, no entanto, diversos pesquisadores que atribuem aos negros o protagonismo da prática e apontam o Carimbó como resultado das folganças na rotina dos escravos. A genealogia do Carimbó, apesar de interessante, está envolta em um véu de incertezas e requer pesquisas mais aprofundadas que, certamente, esbarrarão na dificuldade da falta de documentação e de registros escritos.

Gabbay (2012) faz uma composição histórica do Carimbó no Pará, resgatando seus aspectos identitários, através de produção de textos na imprensa, no website da Campanha Carimbó Patrimônio Brasileiro e nos movimentos socioculturais. Gabbay (2012: 2) reforça a ideia de que o Carimbó tem origem no sincretismo entre as culturas indígena, africana e ibérica. O nome Carimbó deriva do "instrumento de percussão indígena, principal artefato para a realização dos encontros em terreiros, $o$ curimbó, feito de tronco de madeira e pele de animal, é um marco simbólico desta manifestação popular".

Entre as pesquisas que começaram a garantir o reaparecimento do Carimbó como manifestação cultural na década de 60 do Século XX, Torre (2009: 114) destaca as de José Soeiro e Vicente Salles. O primeiro fez um importante trabalho de resgate de letras que compõem 85 peças cantadas por diferentes grupos musicais - Tauapará, Zimba, Os Tapaioaras, Alegria Vigiense, O Beija-Flor, e outros.

As décadas de 70 e 80 desse século foram decisivas para a divulgação do Carimbó, quando chegam às rádios, especialmente através de nomes como Mestre Lucindo e Pinduca. As influências da Indústria Cultural, na década de 90, provocaram novos rumos no desenvolvimento da música do Carimbó, o que fez surgir uma discussão sobre a dualidade entre conservação da tradição e valorização das mudanças históricas na cultura. Gabbay (2012) considerada que a marca tradicional foi defendida durante toda a campanha popular para reconhecimento do Carimbó como patrimônio cultural.

Do ponto de vista artístico, vemos um crescente fortalecimento do estilo tradicional de música, canto e dança, que ganham mais visibilidade nos eventos, na mídia e nas comunidades. Podemos dizer que é uma espécie de mergulho profundo em si mesmo, suas raízes e valores (texto da Campanha Carimbó apud Gabbay, 2012: 8).
Resguardando a importância das releituras do Carimbó e evitando um discurso conservador que quer desqualificar qualquer forma de desdobramento da cultura em novas tendências, é preciso considerar o fato de que a produção para a mídia não mantém compromissos estritos com elementos socioculturais presentes nos movimentos originários. Uma vez que a proposta do presente trabalho é o resgate de representações sobre o feminino, presentes na manifestação cultural, privilegiamos as expressões mais próximas do contexto originário.

\section{Cultura e androcentrismo}

Uma frase emblemática que ecoa da idade média pode sinalizar, inicialmente, a complexa composição de representações excludentes sobre a mulher: "a mulher é um animal que não é nem firme nem estável” (Agostinho apud Beauvoir, 1970: 16).

A associação da mulher com uma marginalidade da vida, sempre destinada à sobrevivência básica, o espaço interior do lar, ou à vida sexual é há muito enfrentada por filosofias feministas e por movimentos de emancipação. Também em teorias mais contemporâneas de cunho feminista é possível encontrar a denúncia dessa marginalização da mulher, como no texto Minha história das mulheres, de Perrot (2007), em que a invisibilidade da mulher está associada à sua atuação limitada ao ambiente privado da família e do lar, sendo o espaço público destinado aos homens.

No espaço contemporâneo, as mulheres protagonizam, cada vez mais, superações dessa condição, assumindo a tarefa do que Beauvoir (1970) chama projeto existencial. No entanto, admitindo-se as grandes transformações que ocorreram em relação aos direitos e conquistas femininas, cabe ainda o questionamento se fizeram, de fato, muitos avanços. Em seu contexto, Beauvoir faz uma crítica contundente, nesse sentido, afirmando que as mulheres nunca opuseram realmente valores femininos aos masculinos, tendo sido os homens que, interessados em manter suas prerrogativas, entenderam que a destinação de um território de domínio feminino, permitiria encerrá-la em suas necessidades.

A distinção que Beauvoir (1970) faz para sustentar essa crítica é entre a possibilidade de constituir projetos existenciais, durante muito tempo destinada somente aos 
homens, que ocupavam o espaço exterior e as conquistas que ele exige, e um certo destino puramente orgânico, disciplinado por um discurso moral sobre a sexualidade, que restringe os instintos animais da fêmea humana em uma imagem de mãe e cuidadora.

Correndo o risco da crítica de atemporalidade das questões suscitadas na presente trajetória reflexiva, não nos furtaremos a citar Ortner, cujas ideias tiveram grande impacto, entre as décadas de 70 e 80, por apontar as justificativas que levaram historicamente as sociedades a admitirem ambas as representações: a separação entre natureza e cultura e a ligação da mulher com a natureza, gerando uma consequente desvalorização universal das mulheres. Nessas justificativas inclui o determinismo biológico e a lógica do sexo dominante, a identificação com algo que a cultura desvaloriza - a natureza -, que coloca como ordem inferior a si própria (Ortner, 1979: 100). O homem, de seu lugar, se dá a característica de um ser cultural que transcende os limites da natureza. Ortner reconhece o risco desnecessário de uma radicalização, quer seja, o de reforçar, ao contrário de sua intenção, a suposta dualidade que, para além das diferenças inquestionáveis entre homens e mulheres, serviria como justificação para limitar os papéis femininos na vida e na sociedade.

Não obstante, não se pode negar que as reverberações atualizadas dessa associação entre devir orgânico na mulher e a natureza, opostos à dimensão da cultura. Já julgamos ter superado conceitualmente a dicotomia natureza versus cultura em nossos dias. No entanto, ela se mantém implícita nas representações sociais e a cultura transita ainda nos discursos como a possibilidade de transcendência das condições naturais.

Já aqui podemos sinalizar uma tipologia de relação de poder que tem o androcentrismo (centralidade do masculino) como base da cultura ocidental. Essa tipologia repete uma estratégia comum à relação entre homens e animais: domesticação por enfraquecimento. Inicialmente, se minam as potências múltiplas da mulher, destinando-a a papéis específicos - a reprodução, o lar, o cuidado - e organizando esses papéis através de um discurso moralizante. Quando as representações se cristalizam na forma de um conceito ou um modelo de mulher ideal, essas estratégias já deram prova de sua eficácia. Foucault (1999: 59), em História da sexualidade $I$, destaca a forma como forças, como as da tradição cristã, incutem, ao mesmo tempo, os discursos disciplinadores e a necessidade de uma confissão a partir de pontos diferentes: "parece-nos, ao contrário, que a verdade, na região mais secreta de nós próprios, não 'demanda' nada mais que revelar-se; e que, se não chega a isso é porque é contida à força, porque a violência de um poder pesa sobre ela".

Alguns sinais de ruptura com essas estratégias de contenção da mulher podem ser visualizados em algumas culturas. As mulheres, no lugar de assumirem os destinos que lhe são atribuídos pela cultura patriarcalista, subvertem a relação de poder e tomam lugares centrais na vida cotidiana e na vida pública. O histórico de ocupação das mulheres no Pará tem a ver com a influência das culturas indígena e negra. A tarefa de cuidado da roça fazia desse ambiente uma expansão do espaço interno da casa, ampliando os domínios femininos no espaço externo. $\mathrm{O}$ trabalho remunerado representava a outra ocupação da mulher. Essas rupturas da reclusão na vida doméstica representam um espaço de força e determinação das mulheres.

\section{Traços da vida cotidiana e imagens da mulher}

As letras de Carimbó que permaneceram no imaginário popular e atravessaram décadas, muito embora com algumas modificações, constituem importantes registros que nos dão pistas não apenas da sua origem, como do cotidiano, das motivações, das experiências, dos conceitos e das visões de mundo de seus praticantes. Procuramos nelas e nas expressões da dança traços culturais da vida cotidiana que apontam para o lugar da mulher nas tramas de poder que sustentam a vida social em determinados contextos.

Torre (2009: 114) reforça que as letras de canções do Carimbó são uma importante fonte de informações sobre a vida cotidiana e as relações sociais no contexto do Carimbó paraense. Destaca os seguintes aspectos:

...o mundo dos roceiros e agregados nas fazendas da região e do trabalho agrícola em geral; o universo social e cultural da pesca num território a cavalo entre o rio e o mar; as realidades vivas e cambiantes dos descendentes das senzalas, e as múltiplas celebrações profanas e religiosas do calendário cultural da área. 
O cenário do Carimbó paraense inclui o trabalho de camponeses envolvidos com a produção agrícola, com extração da borracha, com os engenhos e com a pesca. Os trabalhadores eram antigos escravos, retirantes, pequenos proprietários de roças familiares, pescadores e caçadores. Essa mistura de origens e relações de trabalho reverbera nas letras das canções do Carimbó. Segundo Torre (2009), a região do interior paraense teve uma história de múltiplos processos de fusão étnica marcados por tensões entre relações desiguais de poder entre grupos de gênero e classe.

A marca da escravidão é frequentemente presente nas letras, característica destacada por Torre (2009: 119), que a associa a uma diferença entre as representações atribuídas pelos negros aos patrões e suas mulheres: "o coronel representa os valores da virilidade e a inflexibilidade, o grande patrão, enquanto a esposa dele representa a caridade e a piedade cristãs".

Um primeiro contato com o Carimbó paraense pode suscitar impressões superficiais, partindo-se de uma perspectiva de inspiração feminista: na dança, a imagem sensualizada da mulher pode ser tomada como uma materialização da contenção orgânica ou como sustentação de um mercado marcado pelo interesse falocêntrico; nas canções, várias referências à mulher erotizada, perigosa ou, de outro lado, digna de respeito e cuidado, parecem repetir a dicotomia entre mulher para a vida social e mulher para o prazer, fórmula tão enfaticamente denunciada pelos movimentos feministas. Não obstante, essa análise primeira, não mediada por um conhecimento mais profundo da tradição cultural e de suas influências, pode esconder a imagem de uma mulher forte, resistente, capaz inclusive de inverter relações de poder com o homem, na mesma medida de sua passividade ou violência. São as tias do Carimbó que repetem, na dança, a ritmologia que imprimem à vida prática ou são as meninas que incorporam um tal devir-onça na dança onde homens são dominados e submetidos.

Antecipa-se, aqui, um significativo aspecto histórico-cultural com importância para a discussão. A pesquisadora Elisa Larkin Nascimento, em seu livro Matrizes Africanas no Mundo - Sankofa I, destaca que:
A história da África conhece varias rainhas guerreiras, estadistas que em vários casos enfrentaram na arena militar e política os escravistas e colonizadores europeus. Em Angola há o exemplo da rainha Nzinga, contemporânea de Zumbi, uma soberana competente o suficiente para resistir aos dominadores portugueses e holandeses. Gana oferece a figura da Rainha Yaa Asantewaa, que liderou a guerra dos asante contra o domínio inglês. Esses exemplos não configuram casos isolados, mas confirmam uma tradição que nasce de profundas raízes históricas e culturais. Trata-se do sistema sociopolítico matrilinear, que caracteriza a civilização africana desde os seus primórdios (Nascimento, 2008: 79).

Essas tradições sofreram graves processos de mudanças quando se deu o contato com o colonizador Europeu. E muitos desses povos, sob a influência dos seus colonizadores, gradualmente adotaram características patriarcais. Buscamos esse traço, essas referências, esses contornos herdados, que se apresentam em alguns cantos do país de forma mais acentuada e, em outros pontos, por vezes, de forma confusa e contraditória.

No livro Vozes femininas: Gêneros, mediações $d a$ escrita, Mônica Pimenta Velloso destaca “As tias baianas", personagens quase esquecidas nas profundezas da história suburbana na primeira metade do século XX, trazendo essas mulheres até a superfície de uma história cristalizada que teima em ocultar seu protagonismo nas tramas sociais da pequena África do Rio de Janeiro. Velloso nos aponta um caminho a seguir em busca das heranças culturais trazidas com os negros da África e ressignificada de acordo com a precariedade do meio. Segundo Velloso (1990: 9697), as mulheres negras baianas incorporavam "grande parte desse poder informal, construindo poderosas redes de sociabilidade. Marginalizadas na sociedade global, destituídas de cidadania e de identidade, elas criam novos canais de comunicação sócio-política".

A autora revela uma centralidade diferente das experimentadas na África. Ao retratar as "Tias Baianas" do Rio de Janeiro, Velloso afirma que de tudo ela sabe um pouco:

Conhece o poder de cura das ervas medicinais, sabe rezas para resolver os mais variados problemas, lidera os mutirões de trabalho, dá conselhos à comunidade, é mediadora de conflitos, administradora dos parcos recursos, organizadora das festas etc. (Velloso, 1990: 107). 
A distinção das imagens da mulher e de seus papéis sociais é evidente na cultura regional paraense: "normalmente, era o homem quem fazia só o trabalho fisicamente mais exigente na roça, como a derruba de árvores. A mulher era, porém, quem cuidava da roça durante o ano, convertendo esse espaço em caracteristicamente feminino" (Torre, 2009: 129).

Uma contribuição importante do trabalho de Torre (2009: 133) para nossas discussões diz respeito ao duplo preconceito presente nas referências à imagem feminina: em relação à mulher e à raça. Destaca que em muitas letras do carimbó "que têm como protagonistas mulheres das camadas sociais populares elas aparecem como 'mulatas', 'morenas' e adjetivos similares referentes à cor”. Essas referências tinham a ver também com a classe social, uma vez que as mulatas eram identificadas nas camadas populares, sendo as mulheres brancas sempre associadas às elites, mais resistentes às miscigenações. Geralmente, as imagens das mulheres negras e mulatas eram estereotipadas, sempre associadas ao erotismo e aos instintos. A mulata sexualizada e diabólica que aparece nas canções de Carimbó parece refletir a diferenciação da mulher que positiva o devir orgânico e da mulher contida na cultura.

Um dado social relevante nas informações trazidas por Torre (2009) é o fato da ocorrência de recorrentes estupros sofridos pelas mulheres camponesas por seus patrões. O autor destaca a Dança da onça, onde as tias do Carimbó incorporam a força da onça para inverter as relações de poder e protagonizar uma reação às investidas masculinas com uma implícita violência nos passos que resulta na submissão masculina.

A mulher sexualizada parece ter predominâncias também nas derivações do Carimbó constituídas para adequação à mídia e à indústria fonográfica, reforçando a ideia de dupla destinação da mulher: contenção moral ou uso sexual.

\section{Corpo, dança e presença feminina}

A questão do corpo em devir é ponto de partida para pensar a dança como uma criação e não apenas um instrumento de representação. Se, na dança, os afetos se tornam visíveis não é porque há um esforço deliberado de comunicação de determinadas imagens, mas porque já foi tomado pelas potências dos afetos. Segundo Munhoz (2011:27), “o corpo-dança não é alguém, é muito antes, ninguém. Não é maioria, nem minoria, mas é menor, minoritário. Não tem identidade, registro de nascimento, cadastro, categoria. Não pertence a nenhuma escola, fundação ou teoria. Não quer ensinar nada a ninguém”.

O corpo não tem, assim, nenhum vínculo com uma identidade, não comunica efeitos de cultura, não se restringem à tradição. Um corpo impessoal. O corpo que dança não tem problemas com a condenação ao erótico, ao drama, ao sexual, que pode transgredir discursos sobre formas ideais, adequadas, encerradas em papéis prédeterminados. O corpo é, antes de qualquer contenção, prova de liberdade e de fruição. O corpo que dança rematerializa, recorrentemente, aquela sua parte capturada pelas amarras da tradição.

Moehlecke e Fonseca (2005: 47) falam dos contágios deleuzeanos na dança. Falar de um corpo-dança em devir significa admitir um corpo livre dos limites de uma consciência subjetiva, que escapa para uma zona préreflexiva, imanente, "para além do bem e do mal", "puro acontecimento não submetido às regras de organização do cosmos, do mundo e do eu".

Os acontecimentos que transmutam o corpo acontecem em uma dimensão desprendida de uma temporalidade marcada pela continuidade, pelo mesmo. Seus disparadores se dão na tensão dos encontros, entre múltiplos, entre forças que se conjugam na composição de algo novo. Na dimensão do Fora, são as intensidades (Pelbart, 1989: 123) que movem o corpo e o libertam dos convencionais.

O corpo feminino é aquele que jamais pôde fazer radicalmente a condenação do corpo, pelo seu devir orgânico. Embora os estereótipos da mulher estejam quase sempre associados a um corpo que escapa, que se funde nesse devir, que se liberta no movimento de seus afetos e instintos, é aí mesmo que as rupturas e inversões de poder podem acontecer. Trata-se de deixar fluir essas forças, de positivá-las e mobilizá-las em acontecimentos que, de dentro da tradição, reinventam a cultura, recriam as identidades para, logo depois, deixá-las entregues a novos atravessamentos. Esses movimentos, talvez, carregam a imagem da mulher para um outro espaço, não cristalizado nos limites de um discurso androcêntrico. 


\section{A imagem feminina nas canções e expressões corporais do Carimbó}

Dentre as diversas protagonistas da cultura do Carimbó, uma se destaca com interessante relevância: a tia do Carimbó. Tia Marieta, Tia Bena, Tia Júlia, Tia Martinha, Tia Anália, Tia Zolíria, Tia Maria dos Santos, Tia Bibiana, Tia Luzia Fragata, Tia Cota. Essas são algumas das personagens destacadas por pesquisadores (Amaral e Cordeiro, 2012) dessa cultura. Não há dúvidas que constituem apenas uma fração de mulheres esquecidas pela história, mas que no seu tempo e nos espaços tiveram relevância na propagação dessa cultura.

A figura da tia no Carimbó age como verdadeiro polo aglomerador na comunidade. O próprio termo "tia" rompe os limites do parentesco. A tia representa aquela que se respeita, que se escuta, que, em muitos casos, assume o papel da mãe, a conselheira amável, a juíza implacável, aquela que, algumas vezes, aplica o castigo. Essa figura emblemática tem clara relação com os valores da tradição africana e é recorrente em outros estados como Bahia e Rio de Janeiro.

Eram elas as responsáveis pelos festejos, desde a organização do terreiro (geralmente o terreiro de sua casa), até preparação do cardápio. Mas seu papel não ficava restrito as atividades domésticas; seu protagonismo ultrapassava os limites certamente impostos em outros espaços da sociedade brasileira:

As mulheres tiveram e tem uma participação ativa no Carimbó de Vigia, seja na organização, seja dançando, cantando, compondo ou batendo o Carimbó (tambor). [...] Nos terreiros, chamados posteriormente de quintais, ou nas casas, elas animavam e se divertiam com o Carimbó; aquele que seria símbolo do Estado no século seguinte (Amaral e Cordeiro, 2012: 142).

A participação igualitária ou em destaque da mulher nas manifestações do Carimbó podem ser também identificadas em algumas canções.

\footnotetext{
Aí, panelão, esta é a resposta Porque o desordeiro sempre Ficava sem o couro da costa O Carimbó da Tia Cota Que ela dava no Açaí Era um forró animado
}

\author{
Que nunca tem aqui \\ Lá todo mundo dançava \\ Com prazer e animação \\ Por que tinha medo do panelão \\ Aí, panelão, esta é a resposta \\ Porque o desordeiro sempre \\ Ficava sem o couro da costa \\ A tia Cota festejava com prazer e devoção \\ Dia 8 de dezembro a virgem de Conceição \\ Ela não queria nenhum soldado \\ Que lhe mandasse o tenente \\ Quando brigavam na sala \\ Tia Cota acabava com água quente.
}

Esse Carimbó é de autoria de Adão dos Santos Monteiro que viveu na região da Vigia. Relata um episódio ocorrido em um dos festejos da Tia Cota. Uma briga que só terminou (segundo depoimento do compositor) com a intervenção inusitada da dona da festa com seu caldeirão de água fervente (Amaral e Cordeiro, 2012: 154). O episódio teria, portanto, servido de aviso a outros possíveis brigões. Esse relato se encontra no artigo Entre homens e mulheres, escravizados e libertos, campo e cidade - eis as tias 'negras' do Carimbó na fronteira do saber na cidade da Vigia-PA, de Assunção José Pureza Amaral e Raimundo Paulo Cordeiro.

Vemos aqui a figura feminina munida de toda uma teia de respeitabilidade e reverência, se impondo no conflito, assumindo as rédeas da situação através de uma ação agressiva e destemida.

As relações desenvolvidas na cultura do Carimbó, devido ao envolvimento de uma série de sentimentos ambíguos, se apresentam demasiadamente complexas. A mulher passeia entre a sua figura matriarcal e respeitosa de Tia e se apresenta no meio do terreiro como a dançarina com seus requebrados e remelexos embebidos de sensualidade com uma aparente facilidade. Os diversos relatos de netos e sobrinhos a respeito de suas "tias" libertas da condição de escravas praticando a Dança da Onça e outras danças nos mostra um pouco dessa ambiguidade.

O Carimbó, tanto no que se refere às letras e aos ritmos, é carregado de sensualidade. As coreografias são um capítulo à parte e se configuram como verdadeiros jogos de sedução e poder. Em alguns casos, essa condição abre espaço para uma hipersexualização da mulher em diversas canções. Tanto em letras atuais como nas letras catalogadas no século XX, é possível notar o traço dessa idealização masculina sobre o feminino, em versos, por 
vezes pejorativos, por vezes exaltando a beleza "morena". Essa discussão, desenvolvida por Torre (2009: 133), anteriormente citado, destaca que "a morena bonita", que assombra o imaginário dos compositores e certamente dos demais homens da comunidade aparece em diversas canções como objeto a ser alcançado sempre sobre o signo da sexualidade exacerbada.

Eu vi um pássaro preto araruna que veio de cametá

Xô, Xô, Xô araruna Xô, Xô, Xô Araruna

Não deixa ninguém te pegar

ô que preta é aquela que vem acolá, é

pretinha de angola

é do umarizá

É do umarizá, é do umarizá, é pretinha de angola é do umarizá

ô subi pelo tronco, desci pelo galho, ai morena me apara se não eu caio

Se não eu caio, eu caio, eu caio, ai morena me apara se não eu caio

Eu vi andorinha eu vi a voá, eu vi borboleta nas ondas do mar

Eu vi, eu vi, eu vi, eu vi eu vi borboleta nas ondas do mar

Olha surucucu que quer te picar, no tronco da cana do canaviar.

Eu vi, Eu vi, Eu vi, Eu vi, no tronco da cana do canaviar

Ora! Vamo pegar camarão, nas praias do Maranhão

Ô me rala esse coco, me dá um pedaço, depois tira o leite me dá o bagaço

É assim que a cabra pula, é assim que a nega rebola

Geralmente, as imagens das mulheres negras e mulatas eram estereotipadas, sempre associadas ao erotismo e aos instintos. A mulata sexualizada e diabólica que aparece nas canções de Carimbó reflete a diferenciação da mulher aceita socialmente, a saber, o anjo do lar, o exemplo de mãe. A mulher sexualizada parece ter predominâncias nas derivações do Carimbó constituídas para adequação à mídia e à indústria fonográfica.

A peça Pretinhas de angola se configurou ao longo do tempo como sendo uma "dança" à parte do Carimbó. As características são as mesmas, os instrumentos, os passos e o estilo da letra, mas algumas peculiaridades, como o fato de só mulheres praticarem essa dança, tornaram Pretinhas de Angola uma coreografia independente assim como outras. A peça acima aparece acrescida de alguns versos quando cantada por diferentes cantores, o que pode sugerir que a peça seja composta por diferentes compositores, chegando até os ouvintes como uma música única. As Pretinhas De Angola representam escravas ou libertas que viviam no bairro de Belém conhecido como Umarizal.

As letras apresentam elementos, por vezes, sutis associados à configuração da imagem feminina, de forma que traçaremos algumas especulações na sequência, sem intenção de esgotamento das possibilidades interpretativas.

\author{
Bem-te-vi bateu asa \\ No galho do meu pau, \\ E a malvada morena \\ Pegou na espingarda e matou
}

A recorrência dessa imagem da morena sensualizada reforça as considerações feitas por Torre, no texto $O$ Carimbó e a história social da Grande Vigia, Pará, 1900-1950:

Estas representações da mulata sexualizada ou diabólica continham provavelmente certo grau de realismo, desde o ponto de vista dos Carimbóleiros. As mulheres afrodescendentes procediam das camadas sociais mais carentes, provavelmente foram discriminadas no mercado de trabalho por várias décadas após o fim da escravidão, e muitas vezes viram-se obrigadas a se sustentar com o recurso à prostituição. Não é de estranhar que utilizassem todas as estratégias possíveis, incluindo o engano e a fraude para poder subsistir num mundo marcado pelo patriarcalismo exacerbado e as desigualdades sociais agudas. Porém, a imagem cultural da "mulata de fogo" ou mulher afrodescendente hipersexualizada virou representação patriarcal, convertendo a situação de exploração sexual em qualidade racial inata, como se plasmou na literatura brasileira do século XX (Torre, 2009: 135).

O cotidiano da vida cercado de uma farta e abundante natureza também aparece representado nas coreografias. Alguns passos de Carimbó sugerem rituais de acasalamento, o jogo da conquista e o da cópula animal. Os homens com braços levantados girando em torno de si mesmo, às vezes com uma mão abaixada como a asa da ave que tenta chamar atenção da fêmea. A parceira 
que, por sua vez, dança no seu próprio tempo com seus próprios passos aderindo ou não ao galanteio do parceiro.

A Dança da Onça, a Dança do boto, a da Pomba e o gavião, a Dança do Peru, entre outras: todas essas danças espetaculares com seus símbolos e suas características constituem uma fonte inesgotável de questionamentos. Aqui, destacamos uma histórica proximidade atribuída às representações da mulher e do animal. Ambos, para a cultura ocidental, estão muito mais próximos da vitalidade instintiva associada ao devir orgânico que a racionalidade mediadora requerida pelo discurso androcêntrico. Em outros termos, parece haver uma base comum entre a exclusão do animal e da mulher, ambos colocados em uma zona limítrofe entre características definidoras da plena humanidade - razão, capacidade de modulação das emoções, clara linguagem, etc. - estampadas em uma dimensão dominada pelas forças masculinas e aquelas que dão prova da animalidade, focadas na sensibilidade, nas pulsões do corpo, etc.

No que diz respeito às letras, as observações dos animais também servem de base para poetas compositores que buscam proximidades com seus ouvintes por meio de metáforas e comparações animalescas. Como é o caso da composição $O$ galo e a galinha, de mestre Lucindo. Nela, os episódios cotidianos da vida corriqueira e conjugal se destacam:

O galo e a galinha saíram pra passear, Quando chegou em casa o galo só quer brigar

Coro: O galo faz corocoró, o pato faz chuá, chuá

A picota tô fraco, tô fraco e o peru gulu, gulu

O sentido de galhofa não esconde as tensões provocadas pelas ambuiguidades no que toca os sentimentos ali envolvidos. O poeta não nos fala a respeito das motivações da briga do casal. É preciso mergulhar de cabeça nas entrelinhas, nos despir dos nossos preconceitos e tentar vivenciar, mesmo que à distância, um pouco da realidade das localidades onde o Carimbó é vivenciado e praticado. Sendo o Carimbó uma das principais fontes de divertimento, poderíamos presumir que o "passeio" a que o compositor se refere poderia muito bem seruma roda ocorrida anteriormente.

As mulheres mais novas que não detinham o status de "tia" e a sua consequente bagagem de experiência, e respeitabilidade concedida pelo tempo, eram naturalmente mais vulneráveis a um ambiente masculino e hostil.

$\mathrm{Na}$ roda de Carimbó, no entanto, por vários momentos a mulher troca de lugar com o homem no que toca à submissão e sujeição. Há vários indicativos que demonstram que o patriarcalismo perde sua força nesses espaços. A importância da mulher em todo o processo do fazer acontecer o Carimbó, e seu status e condição de "atração", "peça chave", concede mesmo às mais jovens um certo "empoderamento" e liberdade momentânea. Não seria, portanto, absurdo presumir que toda essa liberdade experimentada nas rodas de Carimbó não pudesse incorrer em desentendimentos futuros na intimidade de cada casal.

Um dado sócio-histórico relevante nas informações trazidas por Torre (2009) é o fato da ocorrência de recorrentes estupros sofridos pelas mulheres camponesas por seus patrões. O autor destaca a Dança da onça, onde as tias do Carimbó incorporam a força da onça para inverter as relações de poder e protagonizar uma reação às investidas masculinas com uma implícita violência nos passos que resulta na submissão masculina.

$\mathrm{Na}$ maioria das composições do Carimbó, encontraremos sentidos não explícitos. No documentário Chama Verequete, de 2002, sob direção de Luiz Arnaldo Campos e Rogério Parreira, Mestre Verequete - importante figura do Carimbó paraense, tido como rei do Carimbó e reverenciado por outros cantores e compositores - relata a história por trás de uma de suas composições:

Eu saí para “inverter" água e me escondi atrás de um pau grosso, e o pessoal dançando Aí quando eu olhei tinha uma moça chorando... Moça! Não sei se era moça, sei que ela estava chorando; aí eu virei para o lado e era um cara que estava (inaudível) "botando quente" em cima dela... Aí quando eu vi, o galo cantou. Aí eu rimei (Verequete, 2002: $\mathrm{s} / \mathrm{n}$ ).

A canção a que Verequete faz referência é a que segue:

Na campina tem um galo

Este galo é cantador

Ele canta à meia noite

Faz chorar quem tem amor

Eu vou pra lá

Eu vou pra lá

Consolar esta morena

Que é pra ela não chorar 
Ao ouvir essa inocente cantiga num primeiro momento, sem o apoio do depoimento do compositor, o sentido original, por ele expresso, dificilmente será apreendido. O depoimento oral do Mestre Verequete é uma fonte que facilita a nossa interpretação e entendimento. O sentido da música está dado pelo próprio autor. No entanto, algumas partes de sua fala nos chamam atenção.

Primeiro precisamos pensar nas informações espaciais dadas pelo compositor. O cenário se assemelha com a maioria dos bairros e cidades do Pará. Os Carimbós eram organizados em terreiros e posteriormente em barracões. As casas afastadas umas das outras por vezes traziam e trazem até hoje porções minguadas de mata nativa. O hábito de realizar necessidades fisiológicas no "mato" era bastante comum, principalmente para os homens. É assim que começa o relato. O compositor saiu para "inverter água" (gíria) atrás de um pau grosso (árvore nativa). Ao longe o pessoal continuava a dançar. Se assistirmos o relato desarmados, tendemos a acreditar que o compositor presenciou apenas uma discussão de casal que resultou no choro da "moça". Mas se levarmos em consideração todo histórico de vulnerabilidade a que estavam sujeitas as mulheres e buscarmos outro sentido para a gíria "botando quente em cima dela", podemos cogitar que o compositor presenciou um ato de violência sexual. $\mathrm{O}$ sentido popular de "moça" em algumas localidades sempre esteve atrelado à condição de menina virgem que começou a menstruar. Ao hesitar se deveria ou não conceder o título de "moça" o compositor procura neutralizar a situação e naturalizar o ato caso a "moça" já tivesse uma vida sexualmente ativa.

Precisamos problematizar o lugar de fala desse compositor, as discussões acerca de consentimentos e a própria caracterização de violência sexual quando não há consentimento em muitos casos, que é uma temática muito recente. É importante notar que, na primeira parte da canção, o compositor em nenhum momento retrata o "não querer" da "moça" e somente na resposta do coro temos uma aproximação do compositor; uma espécie de sentimento de "compaixão", com a possível vítima do ato.

Eu sou a sereia do mar

Eu sou, eu sou.

Tava deitada na areia

Tô ouvindo teu cantar

O Carimbó é muito quente

Da cintura pra baixo eu sou peixe

Da cintura pra cima eu sou gente
A composição Sereia do mar, também do Mestre Verequete, nos ajuda a pensar um pouco sobre as idealizações da mulher. Inspirada num sonho que teve com uma mulher encantada que carregava homens para a perdição nas profundezas das águas, o compositor escreveu essa peça. Aqui se vê a reverberação de uma representação da mulher derivada de uma ideologia cristã que sempre a colocou como sedutora e fonte de perdição. No imaginário dos compositores de Carimbó - que estão imersos num ambiente forjado por inúmeras culturas crenças e conceitos -, a mulher que se apresenta em suas letras assume múltiplas faces; ora é a senhora respeitável, a tia de idade, a sábia; ora é a mulher do sexo fácil, aquela inspira desejo; às vezes a esposa suscetível, a moça indefesa, a mulher encantada, aquela que hipnotiza, seduz e leva suas vítimas à ruína. Isso, de uma certa forma, reproduz a histórica dupla destinação dada à mulher: de um lado, imersa em uma dimensão de mistérios, portadora de poderes inexplicáveis ou sacralizada; de outro, a mulher-corpo, com todas as pulsões não mediadas pela razão afloradas, significando um risco para o equilíbrio e o controle social.

Essa mulher, perdida nas pulsões do corpo, é também criticada em suas opções sexuais e aparece em um discurso moralizador em algumas canções, como é o caso de Maria batalhão, do compositor Pinduca, onde se faz referência pejorativa à promiscuidade feminina.

A Maria Peneirou, Peneirou, Peneirou Maria engravidou, engravidou, engravidou Essa história da Maria o meu pai já me contava toda vez que ela saia peneirava, engravidava Uma vez o motorista outra vez era o vigia até o locutor Que falava: "Alô Maria" toda vez que ela saia

engravidavam a Maria Conheci uma Maria que chamavam batalhão ela ia do soldado até o capitão conhecia de São Paulo até o Maranhão pra falar com o padre mestre só pra pedir perdão.

A diferenciação relativa à vida sexual de homens e mulheres em nossa sociedade revela claramente uma 
moralização das experiências femininas, contidas em discursos de monogamia, e a valorização do padrão poligâmico para os homens. Muitos desses discursos são, inclusive, justificados com argumentos centrados em um determinismo biológico, segundo o qual o instinto promíscuo no homem teria relação com a necessidade, própria dos machos de diferentes espécies de garantir a procriação e a dispersão genética. Vemos, no entanto, que embora argumentos e ideias como essa já tenham sido devidamente transpostos por discursos feministas e igualitários, as reverberações continuam a ter nítida visibilidade em várias dimensões da vida prática.

Por fim, queremos destacar a referência à mulher feita a partir de uma sutil relação de poder em que o homem reivindica o direito de posse, como é o caso da seguinte canção de Pinduca:

Garota do Tacacá
Oi mexe, mexe menina
Pode mexer sem parar
Você agora é a minha
Garota do tacacá
Rala, rala a mandioca
Espreme no tipiti
Separa na tapioca
Apara o tucupi
Prepara meu tacacá
Gostoso com açaí

Notemos dois pontos importantes na canção: a subsunção da mulher no desejo de posse do homem, pelo qual ele pretende encerrá-la em seu projeto existencial, e a destinação da mulher às atividades domésticas, intenção de há muito sustentada no pensamento ocidental, com a reclusão da mulher ao oikos.

É, portanto, interessante notar esse caráter dúbio na manifestação cultural do Carimbó. Se, de um lado, há uma potência feminina garantida por sinais de empoderamento na vida prática e nas danças, como reforçado pela centralidade dos papéis das tias do Carimbó e das tomadas de poder em expressões coreográficas, de outro, evidencia-se discursos conservadores, preconceituosos e dominadores nas letras das canções, denunciando uma permanência dos regimes de contenção da mulher. De certa forma, a superação dessa reverberação exige a desconstrução do próprio conceito de mulher. ...o que mulheres significa foi dado como certo durante tempo demais e o que foi determinado como "referente" do termo foi "fixado", normalizado, imobilizado, paralisado em posições de subordinação. Com efeito, o significado foi fundido com o referente, de tal forma que um conjunto de significados foi levado a ser inerente à natureza real das próprias mulheres. Refundir o referente como o significado e autorizar ou salvaguardar a categoria mulheres como lugar de re-significações possíveis é expandir as possibilidades do que significa ser uma mulher e, nesse sentido, dar condições para e permitir uma capacidade de agir realçada (Butler, 1998: 25)

\section{Considerações finais}

Um aspecto importante a ser destacado das reflexões desenvolvidas diz respeito à evidência de um duplo preconceito presente nas referências à imagem feminina: em relação à mulher e à raça, uma vez que, além das insinuações de contenção da mulher em algumas canções, há indícios de preconceito racial. Em algumas canções levantadas, a imagem da morena sensual é explícita.

As representações da mulher pervertida, bem como a ideia da mulher como propriedade, também aparecem em algumas canções. Esses elementos reforçam a suposição de persistência da visão androcêntrica nos discursos que permeiam a cultura do Carimbó paraense. De outro lado, aspectos do modo de vida cotidiano e expressões corporais e atitudes associadas às danças e práticas da tradição do Carimbó revelam um interessante espaço de ruptura da lógica de dominação e das estratégias de contenção da mulher. Importante estimular a ampliação desse espaço como oportunidade para superação das representações excludentes da mulher.

\section{Referências}

AMARAL, Assunção J.; CORDEIRO, Raimundo P. "Entre homens e mulheres, escravizados e libertos, campo e cidade - eis as tias 'negras' do Carimbó na fronteira do saber na cidade da Vigia-PA". (2012). Cadernos do CEOM, ano 25, n. 37, pp.139-160. 
BEAUVOIR, Simone. (1970). O segundo sexo. 1. Fatos e Mitos. $4^{\text {a }}$ ed. Paris: Gallimard.

BUTLER, Judith. (1998). "Fundamentos contingentes: o feminismo e a questão do pós-modernismo". Trad. Pedro Maia Soares Cadernos Pagu, n. 11, p. 11-42.

FOUCAULT, Michel. (1999). História da Sexualidade I: a vontade de saber. Rio de Janeiro: Edições Graal.

GABBAY, Marcello. (2012). “A conquista do Amazonas: Carimbó e jogo identitário no Pará". ENCONTRO DE PESQUISADORES EM COMUNICAÇÃO E MÚSICA POPULAR, 4, São Paulo. Anais do IV encontro de pesquisadores em comunicação e música popular: linguagens e identidades da música contemporânea. Universidade de São Paulo - ECA/USP, São Paulo: EdUSP, pp.1-14.

MOEHLECKE, Vilene. FONSECA, Tania M. (2005). "Da dança e do devir: o corpo no regime do sutil". Revista do Departamento de Psicologia - UFF, v. 17, n. 1, p. 2944,Jan./Jun.

MUNHOZ, Angélica V. (2011). "Flutuações de um corpodança”. Repertório, Salvador, n. 16, p.24-30.

NASCIMENTO, Elisa L. (2008). A matriz africana no mundo. Coleção Sankofa. São Paulo: Selo Negro.

ORTNER, Sherry B. (1979). "Está a mulher para o homem assim como a natureza para a cultura?". In: ROSALDO, Michelle e LAMPHERE, Louise. A Mulher, a cultura, a sociedade. Rio de Janeiro, Paz e Terra p.95-120.

PELBART, Peter. P. (19890. Da clausura do Fora ao Fora da clausura: loucura e desrazão. São Paulo: Editora Brasiliense.

PERROT, Michelle. (2007). Minha História das mulheres. São Paulo: Editora Contexto.

TORRE, Oscar de La. (2009). "O Carimbó e a história social da Grande Vigia, Pará, 1900-1950”. Revista Estudos Amazônicos, Vol. IV, n. 2, p. 113-150.
VELLOSO, Mônica P. (2003). “As tias baianas tomam conta do pedaço: espaço e identidade cultural no Rio de Janeiro". In: SUSSEKING, Flora; DIAS, Tania; AZEVEDO, Carlito. Vozes femininas: gêneros, mediações e práticas da escrita. Rio de Janeiro: 7Letras, Fundação Casa Rui Barbosa.

VEREQUETE. Curtas Paraenses. In: DOCUMENTÁRIO CENTENÁRIO MESTRE VEREQUETE, BELÉM/PA. Direção: Guaracy Britto Jr, Produção: Cultura Rede de Comunicação. (2002). DVD (54:34), son., col.

Data de recebimento: 21/05/2017.

Data de aceitação: 20/12/2017. 